\title{
Tectonic history of mid-Miocene to present southern Victoria Land Basin, inferred from seismic stratigraphy in McMurdo Sound, Antarctica
}

\author{
S. Henrys, ${ }^{1}$ T. Wilson, ${ }^{2}$ J. M. Whittaker, ${ }^{3}$ C. Fielding, ${ }^{4}$ J. Hall, ${ }^{2}$ and T. Naish ${ }^{1}$ \\ ${ }^{1}$ GNS Science, I Fairway Drive, Avalon, Lower Hutt, PO Box 30-068, New Zealand \\ ${ }^{2}$ School of Earth Sciences, 125 S. Oval Mall, Ohio State University, Columbus, OH 43210-1522, USA \\ ${ }^{3}$ School of Earth Sciences, Victoria University of Wellington, PO Box 600, Wellington, New Zealand and now at: School of Geosciences, \\ University of Sydney, Australia \\ ${ }^{4}$ Department of Geosciences, 214 Bessey Hall, University of Nebraska-Lincoln, NE 68588-0340, USA
}

\begin{abstract}
New and existing seismic reflection data in southern McMurdo Sound have been used to investigate Neogene tectonic history of the Terror Rift adjacent to the Transantarctic Mountains and along the western margin of the West Antarctic Rift System. Seismic data image a young rifting episode that is largely unsampled by CRP and CIROS drill holes. Data reveal up to $3.5 \mathrm{~km}$ of post middle Miocene strata deposited in this part of the NNWSSE trending Terror Rift basin. Mapped fault trends in the southern Terror Rift parallel the axis of the basin and are prominent in a $40 \mathrm{~km}$ wide zone north of Ross Island. Displacement on individual faults in this zone can exceed 100 $\mathrm{m}$ and faults collectively accommodate approximately $10-15 \mathrm{~km}$ of middle Miocene to recent extension.
\end{abstract}

Citation: Henrys, S. A., T. J. Wilson, J. M. Whittaker, C. R. Fielding, J. M. Hall and T. Naish (2007), Tectonic history of mid-Miocene to present southern Victoria Land Basin, inferred from seismic stratigraphy in McMurdo Sound, Antarctica, in Antarctica: A Keystone in a Changing World - Online Proceedings of the 10th ISAES, edited by A. K. Cooper and Raymond C.R. et al.,, USGS Open-File Report 2007-1047, Short Research Paper 049, 4 p.; doi:10.3133/of2007-1047.srp049

\section{Introduction}

Sedimentary basins of the Ross Sea are part of the West Antarctic rift system, a low-lying region 750 to $1000 \mathrm{~km}$ wide situated between Marie Byrd Land and the East Antarctic craton (Fig. 1). Three major, northsouth trending sedimentary basins, the Victoria Land Basin (VLB), the Central Trough and the Eastern Basin form the Ross Sea separated by two broad basement highs, the Coulman and Central Highs. The Northern Basin appears to be the along-strike continuations of the VLB. Geophysical surveys have shown that basins of the western Ross Sea are relatively narrow (100-150 $\mathrm{km}$ ) with maximum sediment thicknesses of up to 14 $\mathrm{km}$ and provide a record of extension and crustal thinning beginning in the early Late Cretaceous and continuing into the Paleogene. Within the VLB the Terror Rift, a $70 \mathrm{~km}$ wide structure extending from Mt. Erebus to Mt. Melbourne, has been identified as the zone of most recent deformation (Cooper et al., 1987; Salvini et al., 1997). Flanking the western margin of the VLB is the Transantarctic Mountains (TAM). With a length of $3500 \mathrm{~km}$ and elevations up to $4500 \mathrm{~m}$ (Robinson and Splettstoesser, 1984), the TAM are one of the major mountain ranges on Earth and represents a major tectonic boundary that divides the stable East Antarctic craton from the thinned continental lithosphere of West Antarctic (Fig. 1) yet there remains uncertainty as to the timing of exhumation, and relationship to rifting in the VLB and ongoing extension in southern Victoria Land. There is also continued debate about whether rifting and relative motion between East and West Antarctica is ongoing.

The focus of the study reported herein is on seismic lines over the southern sector of the Terror Rift, where abundant faulting and volcanic features are present. The goals of this study are to map the fault patterns and subsurface geometries in the area, to provide age constraints for the activity of the Terror Rift, and to integrate these results with previous datasets and interpretations for the rift history of the western Ross Sea region.

Here we take advantage of new seismic reflection data acquired in 2004 (Wilson et al., 2004) that augment existing data sets (Brancolini et al., 1995; Bartek et al., 1996; Hamilton et al., 2001) in the southern VLB that provide clear images of a $3.5 \mathrm{~km}$ thick, Neogene succession. The goal of the cruise was to gain a better understanding of the kinematics and ages of the neotectonic events of the Terror Rift through acquisition of multi-channel and single-channel reflection seismic, magnetic, gravity, and bathymetric data (Hall et al., 2007). Here we focus on McMurdo Sound where we draw on the stratigraphic framework already established (Whittaker, 2005; Fielding et al., 2006; Fielding et al., 2007) to address the following question; does the structure and architecture of the stratigraphic record provide evidence of Neogene rifting of the West Antarctic Rift and the VLB?

\section{Seismic Stratigraphy}

Six post-17 Ma regional unconformities and volcanic horizons have been mapped across the McMurdo Sound seismic grid and define basin wide regional seismic intervals with bounding unconformities (Fielding et al., 2007). An interpreted west to east seismic cross section profile (Fig. 2), located in Figure 1, summarizes the Neogene stratigraphic architecture and shows an example of their relation to late Cenozoic volcanic rocks of the McMurdo Volcanic Group.

The seismic interval up to the reflector designated Rf was drilled in the CRP-2 hole by the Cape Roberts Project and reached as young as $17 \mathrm{Ma}$. The interval 

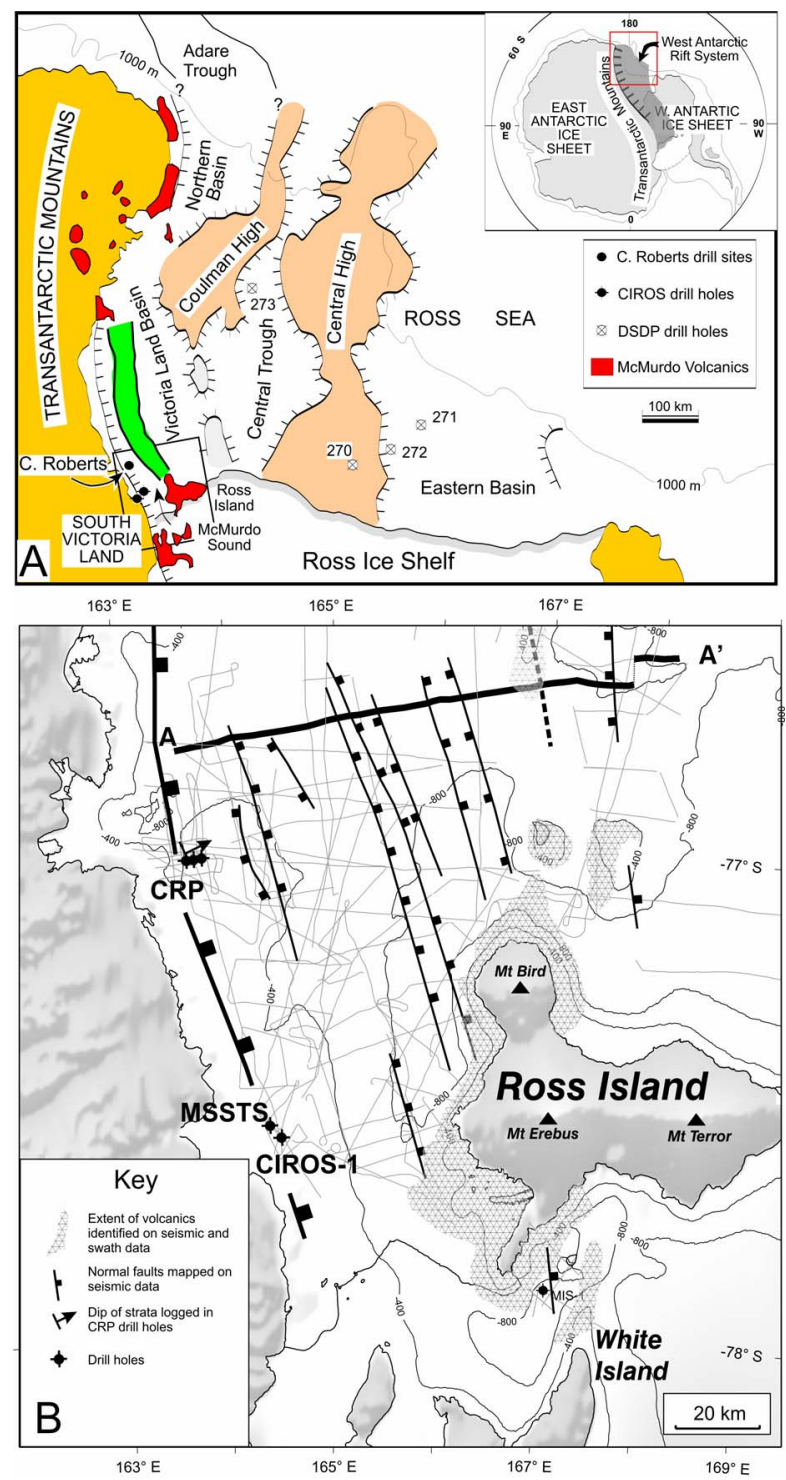

Figure 1. A) Ross Sea rift basins and Transantarctic Mountains are components of the West Antarctic Rift System (inset). Cape Roberts Project drillholes (CRP) sampled strata on the margin of the Victoria Land Basin, providing age constraints for regional seismic reflectors mapped across the basin. Western Ross Sea rifting is inferred to link with spreading in the Adare Trough. B) Detailed map of Southern McMurdo Sound showing the location of the composite cross section (AA'), interpreted in Figure2. The available seismic lines used in this study are shown in grey lines and include a variety of data sets (Brancolini et al., 1995; Bartek et al., 1996; Hamilton et al., 2001; Wilson et al., 2004).

from $\operatorname{Re}$ to $\mathrm{Rg}$ is recognised as an Early Miocene to ?Late Miocene thermal subsidence phase that post dates the VLB main Oligocene-Miocene rifting phase in the VLB (Fielding et al., 2006; Wilson et al., submitted). Figure 2 illustrates that the thermal subsidence phase comprises a sheet of strata that thickens to the basin centre with evidence for clinoform sets. These patterns are interpreted to record accumulation under environmental conditions of glacial advance and retreat into the slowly subsiding basin.

The Renewed Rifting phase (?Late Miocene to Recent) is documented by the interval from $\mathrm{Rg}$ to the seafloor. This interval has been further divided into 1), a lower interval (Rg to $\mathrm{Rj}$ ), in which the section thickens towards a central depocentre, and 2) an upper interval ( $\mathrm{Rj}$ to seafloor), in which more dramatic thickening patterns are complicated by magmatic activity. The youngest part of the stratigraphy was accumulated under the influence of flexural loading imposed by the construction of Ross Island ( $<4.5 \mathrm{Ma})$ (Armstrong, 1978). Within this renewed rifting episode, referred to as the Terror Rift, the reflector labeled Rh (dark green) marks a major rift-related subsidence event and also documents uplift of western margin of the basin. Typically rift flank uplift events generate significantly greater volumes of sediment which are then shed in a major pulse in adjacent basin that are recognisable as a major progradational succession in seismic facies (Japsen et al., 2006) similar to the overall crosssectional geometry observed in Figure 2. That is, the post $\mathrm{Rh}$ section records a subsidence event associated with the rift shoulder uplift, and the upper Ri interval recording the erosion released by this uplift episode.

\section{Structure}

Mapped faults, shown in Figure 1, are major faults that can be traced from one seismic line to another. In general, faults trend NNW-SSE, perpendicular to the dip direction of strata observed at Cape Roberts. These faults define a $70 \mathrm{~km}$ wide axial rift zone called the Terror Rift (Cooper et al., 1987) that narrows to $40 \mathrm{~km}$ just to the north of Ross Island. Individual fault displacement can exceed $100 \mathrm{~m}$ and normal fault plane dips are steeper than $50^{\circ}$. Originally described by Cooper et al. (1987), the Terror Rift is composed of two parts, the Discovery Graben, and the Lee Arch. Cooper et al. (1987) proposed a "magmatically intruded Lee Arch" defining the eastern margin of the Terror Rift. New seismic lines from the Drygalski Ice tongue region, in the north (Hall et al., 2007), to south of Ross Island show that the 'arch' is a structural feature not associated with magmatic intrusion or doming (Hall et al., 2007). Restoration of surfaces $\mathrm{Rg}, \mathrm{Rh}$, and $\mathrm{Ri}$, in Figure 2, by line-length balancing indicated $10-15 \mathrm{~km}$ of extension, and that most of this extension takes place in the interval between $\mathrm{Rg}$ and $\mathrm{Rh}$, co-incident with the major uplift of the western margin identified in the stratigraphic pattern. Faults commonly reach the seafloor at the basin edges although seafloor fault scarps are not pronounced in swath data (Wilson et al., 2004). This post-Early Miocene phase of rifting accommodates up to $\sim 3.5 \mathrm{~km}$ of sediment along the central axis of the 


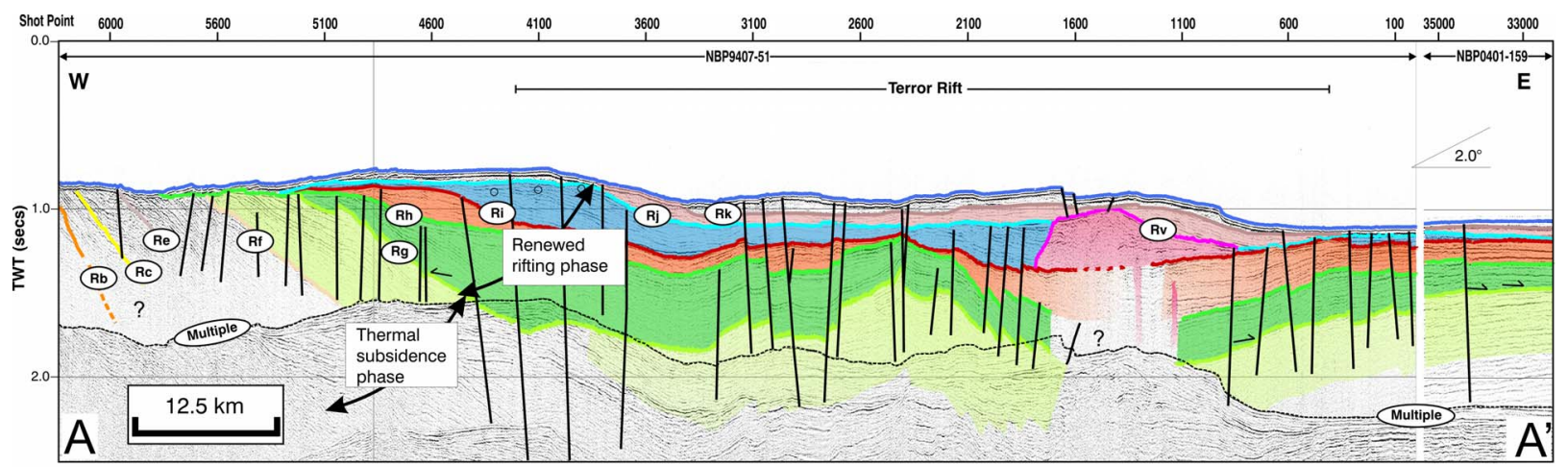

Figure 2. Composite seismic cross-section comprising NBP94-7-51 and NBP0401-159. See (Fielding et al., 2007) for key to seismic reflector coding scheme. The thermal subsidence phase between the purple-grey (Re) and light green ( $\mathrm{Rg}$ ) reflectors and Terror Rift formation is above the light green reflector (Rg to seafloor). The top of the Oligocene-Miocene section cored in the Cape Roberts drill holes is approximated by the beige (Rf) reflector. $\mathrm{Rv}$ is the top of magmatic intrusions.

Terror Rift beneath Ross Island. In comparison, 7-9 km of sediment accumulation is inferred during the Oligocene and Early Miocene main rift phase in the VLB (Wilson et al., submitted).

\section{Discussion}

Extension in the western Ross Sea has been linked to spreading in the Adare Basin (Cande et al., 2000; Davey et al., 2006). Magnetic anomalies, flanking the Adare trough, were interpreted to record relative motion between East and West Antarctica of c. $180 \mathrm{~km}$ between 43 - $26 \mathrm{Ma}$ (Cande et al., 2000) with no evidence of post-early Miocene activity (Müller et al., 2005). The 95\% confidence ellipses, between chrons $13 \mathrm{o}$ and 80 (33-26 Myr), are large and are only constrained by short segments of identified magnetic anomalies. By adding all the VLB extension $(95 \mathrm{~km})$ to the $33-26 \mathrm{Myr}$ time interval (Davey et al., 2006), as an additional constraint, then $\alpha 95$ for the East-West Antarctica Euler pole is reduced. Nonetheless, GPS measurements collected in Marie Byrd Land, indicate no significant motion between East and West Antarctica (Donnellan and Luyendyk, 2004). Also, the lack of diffuse seismicity indicates that most of West Antarctica is no longer actively extending (Winberry and Anandakrishnan, 2003). Our results, on the other hand, do suggest at least10-15 km of post-17 Ma Terror Rift rifting that post-dates 95-135 km of Oligocene-Miocene extension (Wilson et al., submitted). Together the two phases of rifting can account for all of the postulated East-West Antarctic 'plate motion' ( $~ 95 \mathrm{~km})$ but imply a younger age of Antarctic intracontinental deformation and demand re-examination of global plate motion circuits. However, it is also possible that the Cape Roberts drill sites did not capture sediments during the early stages of rifting. The Cape Roberts sites are high on the western flank of the rift, adjacent to the Transantarctic Mountains, and may have been above sea level at the time of rifting or subsequently lifted above sea level and eroded, before becoming a depositional environment around $34 \mathrm{Ma}$.

Young rifting is consistent with other observations and measurements in the western Ross Sea region. Inversion of Rayleigh wave show that the upper mantle (40 - $160 \mathrm{~km}$ depth) shear wave velocities beneath the Terror Rift are up to $6 \%$ slower compared to standard reference earth model (Bannister et al., 2000). P and S wave tomography images (Watson et al., 2006) also reveal a low-velocity region, interpreted as a $200-300 \mathrm{~K}$ thermal anomaly, within the upper mantle centred beneath Ross Island. The presence of the thermal anomaly is corroborated by present-day active volcanism (LeMasurier, 1990) at Mt Melbourne, at the northern end of the Terror Rift (Fig.1), and Mt Erebus, at the southern limit. The large volume of phonolite at Mt. Erebus requires significant basanite production, interpreted to occur by partial melting in a mantle plume (Kyle et al., 1992). Separately, unusually high heat flows $\left(80-126 \mathrm{mWm}^{-2}\right)$ are observed in the Terror Rift and VLB (Blackman et al., 1987; Della Vedova et al., 1992) suggesting abnormally high conductive heat transfer through anomalously thin lithosphere.

Acknowledgements. Captain Mike Watson and the crew of the RVIB Nathanial B Palmer are thanked for their support in acquiring data during NBP0401. SAH, JW, and TRN acknowledges support from the Royal Society of New Zealand Marsden Fund. CRF's participation in the Cape Roberts Project was supported by two out-of-cycle research grants from the Australian Research Council. TJW's participation in the Cape Roberts Project was supported by the National Science Foundation under grant OPP-9527394. Continued work by TJW on the McMurdo Sound basin framework has been supported by NSFOPP-0313974. We thank P. Bart as co-editor, S. Cande, and M Busetti for helpful comments during review.

\section{References}

Armstrong, R. L. (1978), K-Ar dating: Late Cenozoic McMurdo Volcanic Group and Dry Valley glacial history, Victoria Land, Antarctica., New Zealand Journal of Geology and Geophysics, 21(6), 685-698.

Bannister, S., R. K. Snieder and M. L. Passier (2000), Shear-wave velocities under the Transantarctic Mountains and Terror Rift from 
$10^{\text {th }}$ International Symposium on Antarctic Earth Sciences

surface wave inversion. Geophysical Research Letters, 27(2), 281284.

Bartek, L. R., S. A. Henrys, J. B. Anderson and P. J. Barrett (1996), Seismic stratigraphy of McMurdo Sound, Antarctica: implications for glacially influenced early Cenozoic eustatic change? Marine Geology, 130, 79-98.

Blackman, D. K., R. P. Von Herzen and L. A. Lawver (1987), Heat flow and tectonics in the western Ross Sea, Antarctica, in The Antarctic Continental Margin: Geology and Geophysics of the Western Ross Sea, edited by A. K. Cooper and F. J. Davey, pp 179-189, Houston, Texas, Circum-Pacific Council for Energy and Mineral Resources.

Brancolini, G., M. Busetti, A. Marchetti, L. De Santis, C. Zanolla, A. K. Cooper, G. R. Cochrane, I. Zayatz, V. Belyaev, M. Knyazev, O. Vinnikovskaya, F. J. Davey and K. Hinz (1995), Descriptive text for the seismic stratigraphic atlas of the Ross Sea, Antarctica. Washington, D.C., American Geophysical Union.

Cande, S. C., J. M. Stock, R. D. Mueller and T. Ishihara (2000), Cenozoic motion between East and West Antarctica. Nature, 404, $145-150$.

Cooper, A. K., F. J. Davey and J. C. Behrendt (1987), Seismic stratigraphy and structure of the Victoria Land basin, Western Ross Sea, Antarctica, in The Antarctic Continental Margin: Geology and Geophysics of the Western Ross Sea, edited by A. K. Cooper and F. J. Davey, pp 27-66, Houston, Texas, Circum-Pacific Council for Energy and Mineral Resources.

Davey, F., S. C. Cande and J. Stock (2006), Extension in the western Ross Sea region-links between Adare Basin and Victoria Land Basin. Geophysical Research Letters, 33, L20315, doi:10.1029/2006GL027383.

Della Vedova, B., G. Pellis and L. A. Lawver (1992), Heat flow and active tectonics of the western Ross Sea., in Recent Progress in Antarctic Earth Science, Proceedings of the Sixth International Symposium on Antarctic Earth Science, edited by Y. Yoshida, K. Kaminuma and K. Shiraishi, 6, pp 627-637, Saitama, Japan.

Donnellan, A. and B. P. Luyendyk (2004), GPS evidence for a coherent Antarctic plate and for postglacial rebound in Marie Byrd Land. Global and Planetary Change, 42(1-4), 305.

Fielding, C. R., S. A. Henrys and T. J. Wilson (2006), Rift history of the western Victoria Land Basin: a new perspective based on integration of cores with seismic reflection data., in Antarctica: Contributions to Global Earth Sciences, edited by D. K. Futterer, D. Damaske, G. Kleinschmidt, M. H. and T. F., pp 307-316, Berlin Heidelberg New York, Springer-Verlag.

Fielding, C. R., J. Whittaker, S. A. Henrys and T. J. Wilson (2007), Seismic facies and stratigraphy of the Cenozoic succession in McMurdo Sound, Antarctica: implications for tectonic, climatic and glacial history. ISAES This volume.

Hall, J. M., T. J. Wilson and S. A. Henrys (2007), Structure of Central Terror Rift, Western Ross Sea, Antarctica, in Antarctica: A Keystone in a Changing World - Online Proceedings of the 10th ISAES, edited by A. K. Cooper and Raymond C.R. et al., pp, USGS Open-File Report 2007-xxx.

Hamilton, R. J., B. P. Luyendyk, C. C. Sorlien and L. R. Bartek (2001), Cenozoic tectonics of the Cape Roberts Rift Basin and Transantarctic Mountain Front, southwestern Ross Sea, Antarctica., Tectonics, 20, 325-342.

Japsen, P., J. M. Bonow, P. F. Green, J. A. Chalmers and K. LidmarBergstrom (2006), Elevated, passive continental margins: Longterm highs or Neogene uplifts? New evidence from West Greenland. Earth and Planetary Science Letters, 248(1-2), 330.

Kyle, P. R., J. A. Moore and M. F. Thirlwall (1992), Petrologic Evolution of Anorthoclase Phonolite Lavas at Mount Erebus, Ross Island, Antarctica. J. Petrology, 33(4), 849-875.

LeMasurier, W. E. (1990), Late Cenozoic volcanism on the Antarctic Plate; an overview: Volcanoes of the Antarctic Plate and southern oceans, in Antarctic Research Series, edited by W. E. LeMasurier, J. W. Thomson, P. E. Bakeret al, 48, pp 1-17, Washington, American Geophysical Union.

Müller, R. D., S. C. Cande, J. M. Stock and W. R. Keller (2005), Crustal structure and rift flank uplift of the Adare Trough, Antarctica. Geochem. Geophys. Geosyst., 6(11), 1-16.
Robinson, E. S. and J. F. Splettstoesser (1984), Structure of the Transantarctic Mountains determined from geophysical surveys, in Geology of the Central Transantarctic Mountains, edited by M. D. Turner and J. F. Splettstoesser, 36, pp 119-162, Washington, D.C., American Geophysical Union.

Salvini, F., G. Brancolini, M. Bussetti, F. Stroti, F. Mazzarini and F. Coren (1997), Cenozoic geodynamics of the Ross Sea region, Antarctica: crustal extension, interplate strike-slip faulting and tectonic inheritance., Journal of Geophysical Research, 102(669696).

Watson, T., A. Nyblade, D. A. Wiens, S. Anandakrishnan, M. Benoit, P. J. Shore, D. Voigt and J. VanDecar (2006), P and S velocity structure of the upper mantle beneath the Transantarctic Mountains, East Antarctic craton, and Ross Sea from travel time tomography. Geochem. Geophys. Geosyst., 7(7), 1-17.

Whittaker, J. (2005). Cenozoic Structural and Stratigraphic History of McMurdo Sound, Antarctica. School of Earth Sciences. Wellington, New Zealand, Victoria University of Wellington.

Wilson, T. J., S. A. Henrys, M. J. Hannah, R. Jarrad, C. R. Fielding, P. J. Barrett and T. Paulsen (submitted), New rift history for West Antarctica. Geology.

Wilson, T. J., L. A. Lawver, S. A. Henrys, S. Mukasa, H. Horgan, M. Weiderspahn, M. Davis, J. Whittaker, A. Lowe and M. Watson (2004). Cruise Report NBP0401 19 January to 18 February 2004 McMurdo Station to McMurdo Station, Ross Sea, Antarctica, Institute of Geological and Nuclear Sciences Science Report 2004/03, 85p.

Winberry, J. P. and S. Anandakrishnan (2003), Seismicity and neotectonics of West Antarctica. Geophys. Res. Lett., 30(18), SDE 4-1 - SDE 4-3. 